\title{
HUBUNGAN KEKERABATAN KUPU-KUPU BERDASARKAN CIRI MORFOLOGINYA DI TAMAN WISATA ALAM GUNUNG TUNAK SEBAGAI BAHAN PEMBUATAN BUKU PETUNJUK PRAKTIKUM SISTEMATIKA INVERTEBRATA
}

\section{THE PHYLOGENY OF BUTTERFLIES BASED ON THE MORPHOLOGICAL CHARACTERISTICS ON GUNUNG TUNAK NATURE PARK AS MATERIAL TO DEVELOP BOOK OF PRACTICUM INTRUCTIONS OF SISTEMATIC INVERTEBRATAE}

\author{
Aenun Indriyani, Siti Rabiatul Fajri, dan Sri Nopita Primawati \\ Program Studi Pendidikan Biologi FSTT UNDIKMA, Mataram, Indonesia \\ Email: aenunindriyani22@gmail.com, sitirabiatulfajri@ikipmataram.ac.id, \\ srinopitaprimawati@ikipmataram.ac.id
}

Diterima: 4 September 2020. Disetujui: 9 November 2020. Dipublikasikan: 5 Januari 2021

\begin{abstract}
Abstrak: Taman Wisata Alam Gunung Tunak merupakan bentuk kawasan pelestarian alam yang dimanfaatkan untuk pariwisata dan rekreasi alam yang terletak di Desa Mertak, Kecamatan Pujut, Kabupaten Lombok Tengah, Provinsi NTB. Tujuan dengan adanya penelitian ini adalah untuk mengetahui jenis dan hubungan kekerabatan kupu-kupu yang ada di Taman Wisata Alam Gunung Tunak. Jenis penelitian ini adalah deskriptif eksploratif (menjelajah) dengan pendekatan kualitatif dengan menggunakan metode jerat (entrapping methode). Lokasi pengambilan sampel di Butterfly Ecology Center sebagai pos 1 dan untuk pos 2 berada di Trail Road. Kupukupu yang berhasil ditangkap kemudian diidentifikasi berdasarkan karakter morfologinya yang selanjutnya dihitung presentase kemiripannya dan menganalisis hubungan kekerabatannya menggunakan rumus Indeks Kesamaan Sorensen. Berdasarkan hasil dari kupu-kupu yang telah ditangkap berjumlah 25 spesies yang terdiri dari 3 famili yaitu famili Papilionidae, Nymphalidae, dan Pieridae. Berdasarkan dari nilai yang diperoleh selanjutnya dibuat diagram dendogram yang menggambarkan hubungan kekerabatan kupu-kupu. Berdasarkan penelitian yang dilakukan diperoleh hasil bahwa spesies yang memiliki hubungan kekerabatan terdekat jatuh pada spesies Belenois java dan Cepora nerissa dengan presentase kekerabatan sebesar 100\%. Sedangkan spesies dengan hubungan kekerabatan paling jauh jatuh kepada spesies Graphium agamemnon dan Belenois java dengan presentase kekerabatan sebesar 58.6\%. Petunjuk praktikum adalah salah satu sumber informasi bagi mahasiswa pada saat melakukan praktikum di laboratorium dengan nilai $86.7 \%$ dengan kriteria sangat valid atau layak untuk digunakan pada saat proses praktikum Sistematika Invertebrata.
\end{abstract}

Kata Kunci: Hubungan Kekerabatan, Ciri Morfologi, Kupu-kupu, Indeks Kesamaan Sorensen, Petunjuk Praktikum

\begin{abstract}
Gunung Tunak Nature Park are natural conservation area that mainly used for tourism and natural recreation were located in Mertak village, Pujut sub-district, Central Lombok regency, NTB Province. The purpose of this research is to know the type and the phylogeny of butterflies on Gunung Tunak Nature Park. This type of research is descriptive explorative (explore) with qualitative approach by using the roaring methods (entrapping method). The sampling location in Butterfly Ecology Center as post 1 while post 2 located in Trail Road. The butterflies that have been caught and then identified based on the morphological characteristics and then calculated the percentage similarity and analyzed the phylogeny by using the Sorensen Similarity Index. Results showed that there were 25 species of butterflies which were divided into 3 families namely Papilionidae, Nymphalidae, and Pieridae. Based on the values obtained and than made a dendogram diagram which describes the philogeny of butterflies. Based on the research conducted, it was obtained results that species who have the closest kinship relationship fell to Belenois java and Cepora nerissa with a percentage of kinship of $100 \%$. While the species with the farthest kinship relationship fell to Graphium agamemnon and Belenois java with a percentage of kinship of $58.6 \%$. Practicum instructions is one source of information for students while doing practicum in laboratory with a value of $86.7 \%$ with very valid criteria or worth it for using during the Invertebrate Systematics practicum.
\end{abstract}

Keywords: Phylogeny, Morphological Characteristics, Butterflies, Sorensen Similarity Index, Practicum Instructions

\section{PENDAHULUAN}

Lingkungan sebagai sumber belajar memiliki berbagai keuntungan yaitu mudah dijangkau, biaya murah, objek yang diteliti dan permasalahannya beranekaragam. Di NTB khususnya di Pulau Lombok terdapat banyak tempat untuk di jadikan sumber belajar.Salah satunya yang memiliki potensi untuk dijadikan sumber belajar adalah Taman Wisata Alam (TWA) Gunung Tunak.TWA Gunung Tunak ini merupakan bentuk 
kawasan pelestarian alam yang dimanfaatkan untuk pariwisata dan rekreasi alam. Kawasan konservasi ini ditunjuk melalui Surat Keputusan Menteri Kehutanan Nomor: 439/Kpts-II/1997 tanggal 04 Agustus 1997 Seluas 312,02 Hektar. Kemudian pada tahun 1998 berdasarkan Surat Keputusan Menteri Kehutanan Nomor: 52/Kpts-II/1998, tanggal 28 Januari 1998 Taman Wisata Alam (TWA) Gunung Tunak mengalami perluasan sebesar 624 hektar, sehingga luas total TWA Gunung Tunak adalah 936,02 hektar. Sehingga luasnya menjadi seluas $\pm 1.217,91$ hektar [1].

Pada kawasan ini sangat banyak terdapat keanekargaman jenis, sehingga menarik untuk di pelajari dan di teliti serta dapat dijadikan sumber belajar.Salah satu potensi yang dikembangkan di TWA Gunung Tunak adalah kupu-kupu.Terdapat 3 famili yang di temukan di TWA Gunung Tunak yaitu famili Papilionidae, famili Nymphalidae, dan famili Pieridae [1]. Keberadaan kupu-kupu di TWA Gunung Tunak juga dipengaruhi oleh banyak faktor, baik faktor biotik (tumbuhan pakan, tumbuhan inang, suhu, kelembabanudara, intensitas cahaya dan cuaca) dan abiotik (manusia dan hewan) [2].

Berdasarkan potensi yang terdapat di TWA Gunung Tunak belum banyak dimanfaatkan sebagai sumber belajar dalam pembelajarannya.Pemanfaatan bahan dan sumber potensi lokal masih terbatas pada lingkungan sekolah atau perguruan tinggi.Sebagian besar siswa menganggap perlu mengintegrasikan potensi dan kearifan lokal dalam pembelajaran biologi [3].

Dalam mempelajari materi tentang potensi lokal ini akan lebih mudah jika mahasiswa langsung turun ke lapangan, artinya mereka bisa secara langsung mengenali keanekaragaman makhluk hidup dan mampu membedakan satu dengan yang lainnya. Pada hakikatnya semua potensi lingkungan seperti keanekaragaman hayati suatu ekosistem dapat dikembangkan dan dipergunakan sebagai sumber belajar.Sumber belajar perlu diolah menjadi bahan ajar serta dirancang dan disusun menjadi suatu hal yang dapat membelajarkan siswa dan mudah dipahami oleh mahasiswa. Salah satu sumber belajar yang mampu membantu mahasiswa untuk memudahkan dalam pembelajaran lingkungan sekitar ialah berupa petunjuk praktikum. Praktikum memiliki kelebihan tersendiri dengan metode pembelajaran yang lainnya, yaitu: siswa langsung memperoleh pengalaman dan keterampilan dalam melakukan praktikum, mempertinggi partisipasi siswa baik secara individu maupun kelompok, siswa belajar berfikir melalui prinsip-prinsip metode ilmiah atau belajar mempratekkan prosedur kerja berdasarkan metode ilmiah [4].

Jumlah spesies kupu-kupu yang teradapat di Indonesia sekitar 1700 spesies dan jumlahnya ini hanya $10 \%$ dari jumlah keseluruhan ordo Lepidoptera yang ada di dunia termasuk di dalamnya ngengat [5]. Bagian terbesar adalah ngengat atau dikenal juga sebagai kupu-kupumalam. Kupu-kupu tergolong serangga holometabola. Kupu-kupu mempunyai metamorfosis lengkap dengan siklus hidup, yaitu: telur-ulat (larva)kepompong (pupa)-dewasa. Fungsi utama kupukupu dewasa adalah untuk berkembang biak, dan beberapa jenis mempunyai perilaku menarik untuk menemukan pasangannya sampai dengan kawin. Kupu-kupu betina akan meletakkan telurnya untuk kelanjutan siklus hidupnya. Fase dewasa kupu-kupu menggunakan pasokan energi yang tersimpan dari fase ulat, dan mereka menghisap nectar bunga dengan alat mulut (proboscis) yang terjulur, saat itu pula kupu-kupu tersebut membantu menyerbukbunga. Kupu-kupu umumnya aktif pada hari yang cerah, dari matahari mulai muncul sekitar pukul 07.00 pagi sampai matahari ingin tenggelam sekitar pukul 17.00 [1]. Ada kelompok kupu-kupu tertentu, seperti suku Hesperiidae dan anak suku (subfamili) Satyrinae suku Nymphalidae umumnya terbang pagi dan sore sekitar matahari terbit dan terbenam, atau dikenal bersifat krepuskular. Di Indonesia terdapat perbedaan dalam distribusi dan keanekaragaman kupu-kupu di musim penghujan dan musim kemarau [5].

Tujuan penelitian ialah untuk mengetahui jenis dari kupu-kupu yang ada di Taman Wisata Alam Gunung Tunak berdasarkan ciri morfologinya, mengetahui hubungan kekerabatan antar kupu-kupu di TWA Gunung Tunak, dan hasil penelitian selanjutnya diaplikasikan dalam bentuk bahan ajar, bahan ajar yang dibuat berupa Buku PetunjukPraktikum.

\section{METODE PENELITIAN \\ Jenis dan Setting Penelitian}

Jenis penelitian ialah deskriptif eksploratif. Pengambilan sampel menggunakan metode jerat (entrapping method) dengan 2 kali pengambilan sampel dalam sehari (pagi dan sore hari).Titik pengambilan sampel terdiri dari 2 lokasi, lokasi pertama adalah Pos 1 (Butterfly Ecology Center) dan pos 2 (Trail Road). Penelitian ini dilaksanakan pada tanggal 08 Maret 2020 sampai dengan tanggal 15 Maret 2020 di Taman Wisata Alam Gunung Tunak Kabupaten Lombok Tengah. Hasil penelitian tentang hubungan kekerabatan kupu-kupu selanjutnya akan dijadikan buku petunjuk praktikum Sistematika Invertebrata.

\section{Teknik Analisis Data}

Rancangan pembuatan buku petunjuk praktikum Sistematika Invertebrata dapat dilihat dalam rincian sebagai berikut: Hasil penelitian tentang hubungan kekerabatan kupu-kupu akan diolah menjadi buku petunjuk praktikum sistematika invertebrata dengan menggunakan model 4D yang dimodifikasi menjadi model $3 \mathrm{D}$ yang melalui 3 tahap yaitu tahap define, design, dan develop. Kemudian setelah menjadi buku petunjuk praktikum 
selanjutnya masuk kedalam tahap validasi dengan menggunakan 3 ahli yaitu ahli materi, ahli media, dan ahli bahasa. Validasi dilakukan untuk mengetahui bahwa buku petunjuk praktikum yang telah dibuat layak atau tidak digunakan oleh pembaca. Adapun hasil validiasi dari 3 ahli ini adalah Berdasarkan validator ahli bahasa oleh ibu Farida Fitriani, M.Pd telah diperoleh nilai rata-rata $85 \%$ dari 8 komponen penilaian dengan menggunakan skala likert $(5,4,3,2,1)$ yang menunjukkan bahwa Buku Petunjuk Praktikum Sistematika Invertebrata sangat valid/ layak digunakan tanpa revisi. Berdasarkan validator kedua yaitu validator ahli isi/materi oleh Ibu Siti Rabiatul
Fajri S.Si., M.Pd telah diperoleh nilai rata-rata $87,5 \%$ dari 8 komponen penilaian dengan menggunakan skala likert $(5,4,3,2,1)$ yang menunjukkan bahwa Buku Petunjuk Praktikum Sistematika Invertebrata sangat valid/ layak digunakan tanpa revisi. Yang terakhir validator ahli media oleh ibu Sri Nopita Primawati, M.Pd telah diperoleh nilai rata-rata $87,5 \%$ dari 8 komponen penilaian dengan menggunakan skala likert $(5,4,3,2,1)$ yang menunjukkan bahwa Buku Petunjuk Praktikum Sistematika Invertebrata ini sangat valid/layak digunakan tanpa revisi. Mengenai nilai kevalidan/kelayakan dari buku petunjuk yang digunakan dapat dilihat pada Tabel 1.

Tabel 1. Kriteria Kevalidan [13]

\begin{tabular}{cl}
\hline Skala Nilai (100\%) & \multicolumn{1}{c}{ Keterangan } \\
\hline $81-100$ & Sangat valid (tidak revisi) \\
$61-80$ & Valid (tidak revisi) \\
$41-60$ & Cukup valid (revisi) \\
$21-40$ & Kurang valid (revisi) \\
$0-20$ & Sangat tidak valid (revisi) \\
\hline
\end{tabular}

\section{HASIL DAN PEMBAHASAN}

\section{Kondisi umum Taman Wisata Alam Gunung Tunak}

Taman Wisata Alam Gunung Tunak terletak di Desa Mertak Kecamatan Pujut Kabupaten Lombok Tengah Nusa Tenggara Barat.TWA Gunung Tunak ini adalah salah satu bentuk Kawasan Pelestarian Alam yang ada di Lombok, Nusa Tenggara Barat yang terutama dimanfaatkan untuk pariwisata dan rekreasi alam. Kawasan ini merupakan sebuah tanjung yang menjorok ke Laut. Di lihat dari vegetasinya, kawasan TWA Gunung Tunak ini merupakan satu-satunya kawasan dengan kondisi hutan yang masih utuh. Sebagian besar kawasan bertopografi datar dan sebagian merupakan perbukitan. Bukit tertinggi mencapai ketinggian 105 meter di atas permukaan laut [1].

Berbagai jenis flora dan fauna dapat ditemukan di kawasan ini, dan salah satu keanekaragaman fauna yang menarik perhatian adalah berbagai jenis kupu-kupu. Banyaknya jenis kupu-kupu di kawasan ini sangat menarik perhatian karena warna sayapnya yang bermacam-macam dan beraneka warna. Di dalam Kawasan TWA Gunung Tunak ini sangat banyak terdapat jenis kupu-kupu lebih dari 40 jenis yang ada di temukan disana oleh [1]. Hal ini dipengaruhi oleh beberapa faktor yaitu sinar matahari, tumbuhan inang dan sumber makanan bagi kupu-kupu.

\section{Spesies kupu-kupu yang ditemukan di TWA Gunung Tunak}

Berdasarkan hasil analisis identifikasi, ditemukan beberapa spesies kupu-kupu dari masingmasing pos, dengan melakukan 3 kali pengulangan yang dapat disajikan pada Tabel 2 di bawah ini:
Berdasarkan Tabel 2, menyebutkan bahwa telah ditemukan 25 spesies kupu-kupu yang ada di TWA Gunung Tunak khusunya pada pos 1 dan pos 2 yang merupakan jalur lintasan bagi kupu-kupu tersebut. Pada pos 1 ditemukan 13 jenis kupu-kupu yaitu Graphium agamemnon,Graphium doson, Belenois java, Appias paulina, Papilio peranthus, Euploea tulliolus, Cepora perimale, Papilo memnon, Ixias reinwardtii, Cepora nerissa, Vindula dejone, Leptosia nina, dan Eurema hecabe.Sedangkan spesies yang ditemukan pada pos 2 berjumlah 19 spesies yang diantaranya Graphium agamemnon, Tirumala hamate, Graphium doson, Ariadne specularia, Papilio demoleus, Papilio peranthus, Papilio polytes (betina), Euploea tulliolus, Cepora perimale, Pachliopta aristolochiae, Danaus genutia, Ariadne merione, Ixias reinwardtii, Cepora nerissa, Hebomoia glaucippe, Catopsilia Pomona, Papilio polytes (jantan), Delias oraia, dan Hypolimnas bolina.

\section{Hubungan Kekerabatan Kupu-kupu di TWA Gunung Tunak}

Berdasarkan ciri morfologi kupu-kupu pada saat melakukan proses identifikasi, selanjutnya data morfologi dapat digunakan untuk mengetahui tingkat kekerabatan dengan menganalisis indeks kesamaan menggunakan rumus Indeks Kesamaan Sorensen dengan hasil pada Tabel 3. 
Tabel 2. Spesies Kupu-kupu di TWA Gunung Tunak

\begin{tabular}{|c|l|l|c|c|}
\hline No & \multicolumn{1}{|c|}{ Spesies } & \multicolumn{1}{|c|}{ Famili } & Pos 1 & Pos 2 \\
\hline 1 & Graphium agamemnon & Papilionidae & $\sqrt{ }$ & $\sqrt{ }$ \\
\hline 2 & Tirumala hamate & Nymphalidae & & $\sqrt{ }$ \\
\hline 3 & Graphium doson & Papilionidae & $\sqrt{ }$ & $\sqrt{ }$ \\
\hline 4 & Belenois java & Pieridae & $\sqrt{ }$ & \\
\hline 5 & Ariadne specularia & Nymphalidae & & $\sqrt{ }$ \\
\hline 6 & Appias paulina & Pieridae & $\sqrt{ }$ & \\
\hline 7 & Papilio demoleus & Papilionidae & & $\sqrt{ }$ \\
\hline 8 & Papilio peranthus & Papilionidae & $\sqrt{ }$ & $\sqrt{ }$ \\
\hline 9 & Papilio polytes $($ betina $)$ & Papilionidae & & $\sqrt{ }$ \\
\hline 10 & Euploea tulliolus & Nymphalidae & $\sqrt{ }$ & $\sqrt{ }$ \\
\hline 11 & Cepora perimale & Pieridae & $\sqrt{ }$ & $\sqrt{ }$ \\
\hline 12 & Pachliopta aristolochiae & Papilionidae & & $\sqrt{ }$ \\
\hline 13 & Danaus genutia & Nymphalidae & & $\sqrt{ }$ \\
\hline 14 & Ariadne merione & Nymphalidae & & $\sqrt{ }$ \\
\hline 15 & Papilio memnon & Papilionidae & $\sqrt{ }$ & \\
\hline 16 & Ixias reinwardtii & Pieridae & $\sqrt{ }$ & $\sqrt{ }$ \\
\hline 17 & Cepora Nerissa & Pieridae & $\sqrt{ }$ & $\sqrt{ }$ \\
\hline 18 & Hebomoia glaucippe & Pieridae & & $\sqrt{ }$ \\
\hline 19 & Catopsilia pomona & Pieridae & & $\sqrt{ }$ \\
\hline 20 & Vindula dejone & Nymphalidae & $\sqrt{ }$ & \\
\hline 21 & Papilio polytes $(j a n t a n)$ & Papilionidae & & $\sqrt{ }$ \\
\hline 22 & Leptosia nina & Pieridae & $\sqrt{ }$ & \\
\hline 23 & Eurema hecabe & Pieridae & $\sqrt{ }$ & \\
\hline 24 & Delias oraia & Nymphalidae & & $\sqrt{ }$ \\
\hline 25 & Hypolimnas bolina & & & \\
\hline
\end{tabular}

Tabel 3. Persentase Kesamaan Kupu-kup di TWA Gunung Tunak

\begin{tabular}{|c|l|c|}
\hline No & \multicolumn{1}{|c|}{ Nomor Spesies } & Persentase \\
\hline 1 & \multicolumn{1}{|c|}{4,17} & $100 \%$ \\
\hline 2 & 1,7 & $96,2 \%$ \\
\hline 3 & $4,17,23,6,10,19$ & $94,7 \%$ \\
\hline 4 & $1,7,11,9$ & $92,3 \%$ \\
\hline 5 & $1,7,11,9,8$ & $91,7 \%$ \\
\hline 6 & $5,13,22,24$ & $90 \%$ \\
\hline 7 & $1,7,11,9,8,12$ & $88,9 \%$ \\
\hline 8 & $1,7,11,9,8,12,3,2,25,15$ & $88 \%$ \\
\hline 9 & $1,7,11,9,8,12,3,21$ & $84,6 \%$ \\
\hline 10 & $4,17,23,16$ & $84,2 \%$ \\
\hline 11 & $1,7,11,9,8,12,3,21,20$ & $81,8 \%$ \\
\hline 12 & $1,7,11,9,8,12,3,21,20,14$ & $81,5 \%$ \\
\hline 13 & $6,10,19,5,13,22,24$ & $81,4 \%$ \\
\hline 14 & $4,17,23,16,6,10,19,5,13,22,24$ & $75,3 \%$ \\
\hline 15 & $1,7,11,9,8,12,3,21,20,14,2,25,15$ & $70,1 \%$ \\
\hline 16 & $4,17,23,16,6,10,19,5,13,22,24,18$ & $63,2 \%$ \\
\hline 17 & $4,17,23,16,6,10,19,5,13,22,24,18$, & $58,6 \%$ \\
\hline & $1,7,11,9,8,12,3,21,20,14,2,25,15$ & \\
\hline
\end{tabular}

Berdasarkan Tabel 3, menyebutkan bahwa spesies nomor 4 yaitu Belenois java dan spesies nomor 17 yaitu Cepora nerissa memiliki tingkat hubungan kekerabatan paling tertnggi dengan presentase kekerabatan sebesar $100 \%$. Sedangkan untuk spesies nomor 4 yaitu Belenois java dan spesies nomor 1 yaitu Graphium agamemnon memiliki tingkat hubungan kekerabatan yang paling rendah yaitu dengan presentase kekerabatan sebesar 58.6\%. 


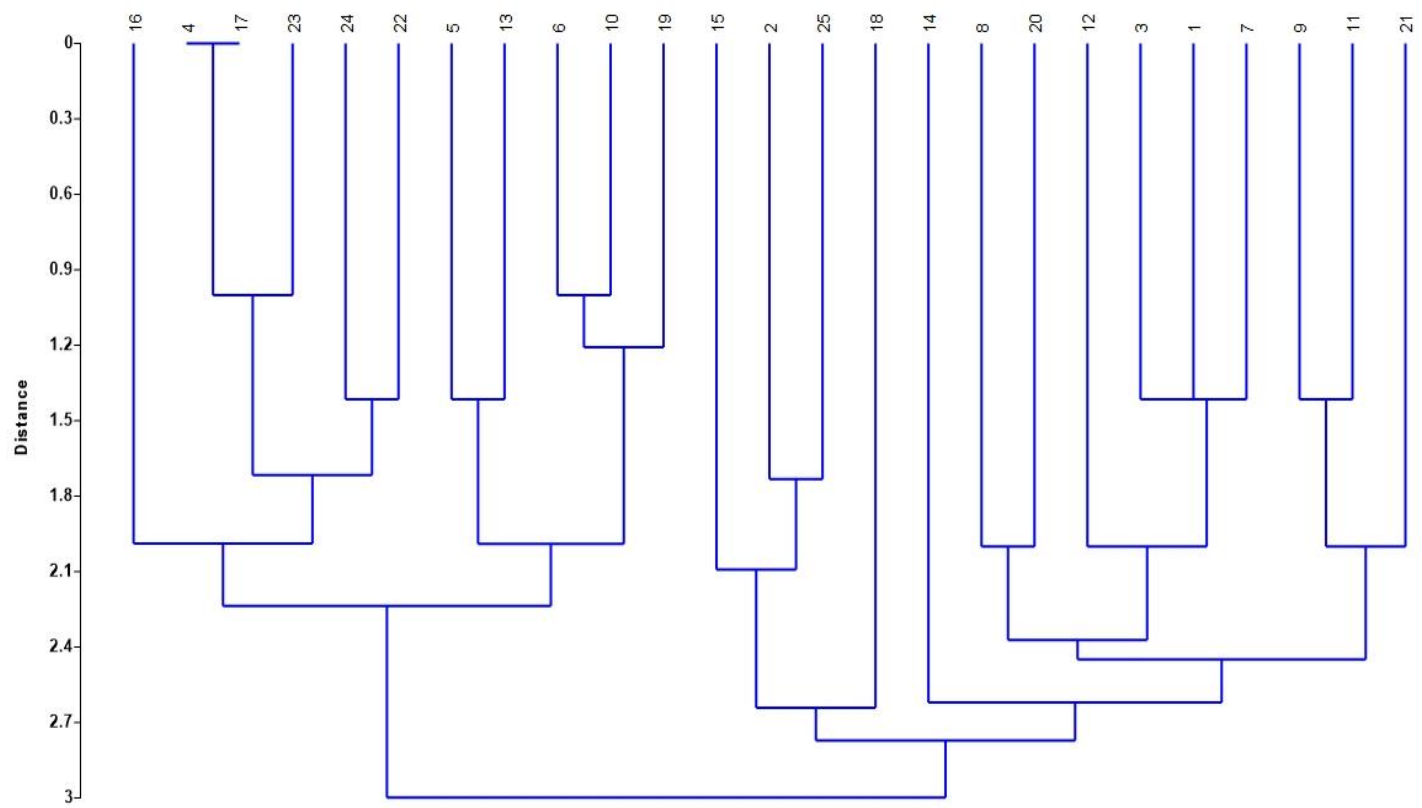

Gambar 1. Kekerabatan kupu-kupu juga dapat dilihat lebih jelas dengan diagram dendogram di bawah ini.

Pada saat melakukan penelitian di Taman Wisata Alam Gunung Tunak, DesaMertak, Kec. Pujut, Kab. Lombok Tengah Nusa Tenggara Barat pada tanggal 08 Maret 2020-15 Maret 2020, telah ditemukan 25 spesies kupu-kupu (Rhopalocera $s p$ ) yang terdiri dari 3 famili yaitu famili Nymphalidae, famili Papilionidae, dan famili Pieridae (Tabel 1). Spesies yang peneliti temukan ini hanya sebagian saja jika dibandingkan dengan penemuan dari peneliti sebelumnya yang menemukan 48 spesies kupu-kupu di TWA Gunung Tunak pada tahun 2018. Dari semua jumlah spesies yang ditemukan peneliti sebelumnya ini semuanya masuk kedalam 3 famili yaitu famili Papilionidae, famili Nymphalidae, dan famili Pieridae. Dari 25 jenis kupu-kupu yang peneliti dapatkan itu kemudian peneliti identifikasi berdasarkan 26 ciri morfologinya [6]. Diantaranya adalah ukuran tubuh besar, ukuran tubuh kecil, ukuran tubuh sangat besar, mulut tipe penghisap, antenna seperti tali, sayap depan lebih panjang, kaki depan sangat kecil, kaki depan normal, kupu-kupu yang terbang siang, kupu-kupu yang terbang malam, bonggol antenna membengkok, ujung antenna berbonggol, sayap belakang ada perpanjangan ekor, berwarna putih, kuning/oranye dengan bercak hitam, berwarna kuning, cokelat dengan dihiasi renda-renda pada sayap depan atau belakang, sayap bersisik, terdapat bintik-bintik atau pita yang berwarna cerah, badan gemuk, berwarna kusam/suram, sayap hitam/gelap, tubuh ramping, sayap belakang lebar membulat, antenna membesar pada pucuk, proboscis absen/vestigial, sayap berbintik cokelat, dan ada sayap (Tabel 3).
Berdasarkan hasil analisis kekerabatan kupu-kupu dengan menggunakan Indeks Kesamaan Sorensen pada Tabel 3 menyebutkan bahwa spesies kupu-kupu dengan nomor 4 dan nomor 17 memiliki tingkat kesamaan atau kemiripan yang paling tinggi yaitu $100 \%$, dimana spesies nomor 4 adalah Belenois java dan spesies nomor 17 adalah Cepora nerissa yang keduanya berasal dari famili yang sama yaitu Pieridae [6]. Hal ini dapat dilihat di dalam tabel indeks kesamaan yang paling tertinggi. Selain itu, spesies nomor 4 dan nomor 17 memiliki 9 karakter yang sama diantaranya memiliki ukuran tubuh yang kecil, mulut tipe pengisap, kaki depan sangat kecil, kupu-kupu yang terbang siang hari, berwarna putih, kuning/oranye dengan bercak hitam, sayap bersisik, tubuh ramping, sayap belakang lebar membulat, dan ada sayap. Hal ini telah diperkuat oleh penelitian yang dilakukan oleh Ali yang menyatakan bahwa spesies yang memiliki nilai yang paling tinggi itu dapat dilihat dari indeks kesamaan tertinggi dibanding dengan yang lainnya, dan dilihat dari banyaknya karakteristik morfologi yang sama yang dimiliki oleh antar spesies [8].

Spesies nomor 1 dan nomor 7 adalah spesies kedua yang memiliki tingkat kesamaan yang paling tinggi yaitu $96.2 \%$, dimana spesies nomor 1 adalah Graphium agamemnon dan spesies nomor 7 adalah Papilio demoleus yang keduanya berasal dari satu famili yaitu Papilionidae. Spesies nomor 1 dan spesies 7 memiliki 13 karakter yang sama diantaranya yaitu ukuran tubuh besar, mulut tipe pengisap, sayap depan lebih panjang, kaki depan normal, kupu-kupu yang terbang di siang hari, bonggol antenna membengkok, ujung antenna berbonggol, sayap bersisik, terdapat bintik-bintik 
atau pita yang berwarna cerah, tubuh ramping, antenna membesar pada pucuk, proboscis absen/vestigial, dan ada sayap.

Begitu pula dengan spesies selanjutnya semakin ke bawah semakin rendah pula tingkat kesamaan atau kemiripan yang mereka miliki. Hal ini dilihat dari proses pengklasifikasianya. Semakin ke atas urutan tingkatan klasifikasinya, maka hubungan kekerabatan antar spesies semakin jauh. Begitu pula sebaliknya, jika urutan tingkatan klasifikasinya semakin ke bawah/ menurun maka hubungan kekerabatan antar spesies semakin dekat. Hal ini sesuai dengan pendapat Ningtyas yang menyatakan bahwa semakin mendekati $100 \%$ maka hal itu menunjukan tingkat kesamaan atau kemiripannya semakin tinggi pula, namun jika semakin jauh dari $100 \%$ maka menunjukan tingkat kesamaan atau kemiripannya semkin rendah. Hal ini dapat dilihat dari spesies nomor $4,17,23,16$, $6,10,19,5,13,22,24,18$ dengan spesies nomor 1 , $7,11,9,8,12,3,21,20,14,2,25,15$ yang merupakan spesies dengan tingkat kesamaan atau kemiripan yang paling rendah atau dengan kata lain mereka memiliki banyak perbedaan karena hanya memiliki 5 karakter yang sama sehingga hubungan kekerabatan mereka juga sangat jauh di bandingkan dengan yang lainnya yaitu sebesar 58,6 \% [9].

Berdasarkan hasil penelitian yang peneliti lakukan, tidak semua spesies kupu-kupu dapat ditemukan di semua titik pengambilan, spesies kupu-kupu yang ditemukan pada titik yang berbeda-beda. Hal ini juga dimungkinkan karena kondisi lingkungan tempat kupu-kupu (Rhopalocera $s p$ ) ini hidup yang berbeda-beda. Hal ini diperkuat oleh Sarma,et.al., yang menyatakan bahwa Keberadaan kupu-kupu di TWA Gunung Tunak juga dipengaruhi oleh banyak faktor, baik faktor biotik (tumbuhan pakan, tumbuhan inang, suhu, kelembaban udara, intensitas cahaya dan cuaca) dan abiotik (manusia dan hewan) [2]. Seperti yang telah dilakukan peneliti sebelumnya di TWA Gunung Tunak [1] yang menemukan 48 jenis kupu-kupu yang terdiri dari 3 famili yaitu famili Papilionidae dengan 10 spesies yang diantaranya Graphium agamemnon, Graphium aristeus, Graphium doson, Pachliopta aristolochiae, Papilio canopus, Papilio demoleus, Papilio Memnon, Papilio peranthus, Papilio polytes, Troides helena. Famili Nymphalidae dengan 23 spesies yang diantaranya Ariadne specularia, Cethosia penthesilea, Cupha erymanthis, Danaus affinis, Danaus chrysippus, Danaus genutia, Euploea climena, Euploea eunice, Euploea modesta, Euploea tulliolus, Hypolimnas bolina, Ideopsis juventa, Junonia erigone, Junonia iphita, Junonia hedonia, Mycalesis mineus, Neptis hylas, Phaedyma collumela, Pareronia valeria, Polyura hebe, Tirumala hamata, Tirumala septentrionis, Vindula dejone. Famili Pieridae dengan 15 spesies diantaranya Appias albina, Appias lyncida, Appias paulina, Belenois java, Catopsilia pomona, Catopsilia scilla, Cepora iudith, Cepora nerissa, Cepora perimale, Cepora temena, Delias oraia, Eurema hecabe, Hebomoia glaucippe, Ixias reinwardtii, Leptosia nina.

Cuaca pada saat pengambilan pada tiap pos sama yaitu cerah dengan tingkat intensitas cahaya yang berbeda-beda. Intensitas cahaya yang dibutuhkan oleh kupu-kupu 159 - 596,25 cd/m [10]. Intensitas cahaya yang tinggi tentunya meningkatkan temperatur udara dan menurunkan kelembaban di sekitar pos/ titik pengambilan. Waktu pengambilan kupu-kupu dilakukan sebanyak 2 kali sehari dengan pengambilan pertama dilakukan pada tanggal 09 Maret 2020, pagi pukul 08.00-10.30 WITA dengan kelembaban $52 \%$ dan suhu $41^{\circ} \mathrm{C}$ dan pengambilan kedua pada pukul 14.00-16.00 WITA. Pada tanggal 12 Maret 2020 , Pengambilan pertama dilakukan pada pukul 08.00-10.10 WITA dengan kelembaban $62 \%$ dan suhu $38^{\circ} \mathrm{C}$ dan pengambilan kedua dilakukan pada pukul 14.15-16.20 WITA. Pada tanggal 15 Maret 2020, pengambilan pertama dilakukan pada pukul 09.00-11.50 WITA dengan kelembaban $40 \%$ dan suhu $41^{\circ} \mathrm{C}$ dan pengambilan kedua pada pukul 14.30-17.00 WITA. Hal ini diperkuat oleh [1] yang menyatakan bahwa aktivitas kupu-kupu biasanya dimulai jika matahari sudah terbit (sekitar pukul 07.30 WITA) sampai dengan matahari hendak terbenam (sekitar pukul 17.30 WITA). Namun jika cuaca mendung atau hujan, kupu-kupu tidak terlihat karena bersembunyi dibalik dedaunan.

Keberadaan kupu-kupu di TWA Gunung Tunak sangat beragam, ada yang berukuran besar dan ada yang berukuran kecil berdasarkan jenisnya. Selain suhu, kelembaban, dan yang lainnya, diperkirakan kecepatan atau kekuatan angin juga bisa mempengaruhi cara terbang dan pola makan kupu-kupu. Karena dengan adanya kecepatan atau kekuatan angin kita bisa mengetahui seberapa tinggi kupu-kupu itu terbang. Jika di TWA Gunung Tunak itu kekuatan anginnya sangat rendah, maka kupu-kupu akan harus lebih berusaha lagi untuk membuka sayapnya agar bisa terbang lebih tinggi. Begitu juga sebaliknya jika anginnya cukup untuk membuat mereka bisa terbang tinggi, itu akan lebih memudahkan mereka dalam mencari sumber makanan khusunya bunga yang ada dipepohonan yang tinggi. Karena rata-rata sumber makanan yang dibutuhkan oleh kupu-kupu berada di pepohonan yang berbunga yang ukurannya cukup besar dan tinggi.Sehingga banyak kupu-kupu yang berkumpul untuk mencari makan pada pohon yang berbunga ini.

Menurut [11] keragaman vegetasi merupakan sebagai sumber pakan yang penting bagi kehidupan kupu-kupu selain tempat berlindung dari predator dan tempat berkembang biak. Sari bunga merupakan sumber pakan kupukupu, oleh karena itu semakin banyak cairan sari 
bunga yang tersedia dengan melimpahnya tanaman berbunga penghasil sari bunga maka jumlah dan keberagaman kupu-kupu dalam daerah tersebut semakin banyak dan beragam. Pada pos 1 struktur vegetasi penyusun hutannya adalah pepohonan, semak, dan herba. Sehingga pada pos ini sangat cocok dijadikan tempat untuk bereproduksi dan berkembang biak. Selain itu, pada pos 1 terdapat pula sumber makanan yang dapat memenuhi kebutuhan dari kupu-kupu tersebut.Untuk pos 2 struktur vegetasi penyusun hutannya terdiri dari pepohonan dan semak. Untuk pos ini sangat cocok bagi kupu-kupu untuk mencari makanan, karena pohon yang ada di pos 2 ini semuanya memiliki bunga, yang mana bunga-bunga itu akan menghasilkan sarinya untuk dikonsumsi atau dimakan oleh kupu-kupu.

Peran kupu-kupu juga dapat dijadikan sebagai bioindikator kualitas lingkungan.Dimana pengertian dari bioindikator itu sendiri adalah organisme hidup seperti tanaman, hewan, plankton, dan mikroba yang digunakan untuk menyaring kesehatan ekosistem alami dan lingkungan.Indikator Biologi dapat memantau secara kontinyu dan merupakan petunjuk yang mudah untuk memantau terjadinya pencemaran.Salah satu hewan yang bisa dijadikan bioindikator adalah kupu-kupu, jika di dalam suatu lingkungan itu masih terdapat banyak kupu-kupu berarti lingkungan itu masih dalam keadaan baik atau bersih [12].

\section{KESIMPULN}

Berdasarkan hasil penelitian dan analisis data yang telah peneliti lakukan, dapat ditarik beberapa kesimpulan yaitu, pertama Berdasarkan 26 ciri morfologi yang digunakan untuk mengidentifikasi jenis kupu-kupu yang ada di TWA Gunung Tunak, ditemukan 25 spesies kupu-kupu yaitu Graphium agamemnon, Tirumala hamata, Graphium doson, Belenois java, Ariadne specularia, Appias paulina, Papilio demoleus, Papilio peranthus, Papilio polytes (B), Euploea tulliolus, Cepora perimale, Pachliopta aristolochiae, Danaus genutia, Ariadne merione, Papilio memnon, Ixias reinwardtii, Cepora nerissa, Hebomoia glaucippe, Catopsilia Pomona, Vindula dejone, Papilio polytes (J), Leptosia nina, Eurema hecabe, Delias oraia, Hypolimnas bolina. Kedua, Kekerabatan terdekat dimiliki oleh Belenois java dan Cepora nerissa dengan presentase kekerabatan sebesar $100 \%$. Sedangkan spesies dengan tingkat hubungan kekerabatan paling jauh yaitu Graphium agamemnon dan Belenois java dengan presentase kekerabatan sebesar 58.6\%. Ketiga, Buku petunjuk praktikum yang telah dibuat ini digunakan untuk membantu mahasiswa pada saat melakukan praktikum Sistematika Invertebrata di laboratorium karena petunjuk ini sudah melewati tahap validasi dengan nilai $86.7 \%$ dalam kriteria sangat layak untuk digunakan.

\section{DAFTAR PUSTAKA}

[1] Hasanah, U., Nofisulastri, N., \& Safnowandi, S. (2020). Inventarisasi Serangga Tanah di Taman Wisata Alam Gunung Tunak Kabupaten Lombok Tengah. Bioscientist: Jurnal Ilmiah Biologi, 8(1), 126-135.

[2] Sarma, K., Kumar, A., Devi, A., Mazumdar, K., Krishna, M., Mudoi, P., \& Das, N. (2012). Diversity and habitat association of butterfly species in foothills of Itanagar, Arunachal Pradesh, India. Cibtech Journal of Zoology, 1(2), 67-77.

[3] Jayanti, U. N. A. D., Susilo, H., \& Suarsini, E. (2018, February). Analisis kebutuhan bentuk sumber belajar dan media pembelajaran biologi berbasis potensi lokal untuk kelas $\mathrm{x}$ sma di provinsi Lampung. In Seminar Nasional Pendidikan IPA 2017 (Vol. 2).

[4] Bahri, D. S. (2014). Strategi Belajar Mengajar Jakarta: Rineka Cipta.

[5] Peggie, D. (2006). Panduan praktis kupukupu di Kebun Raya Bogor. LIPI.

[6] Astuti, D. S. (2016). Perhitungan Tingkat Kekerabatan Ordo Lepidoptera (Kupu Kupu) di Tahura Bromo Karanganyar Menggunakan Indeks Kesamaan Sorensen dan Dendogram. In Proceeding Biology Education Conference: Biology, Science, Enviromental, and Learning (Vol. 13, No. 1, pp. 592-602).

[7] Astuti, D. S., \& Ruslan, R. (2019). Analisis Tingkat Kemiripan Orthoptera Menggunakan Indeks Sorensen dan Dendogram di Hutan Bromo Karanganyar Jawa Tengah, Indonesia. Bioeksperimen: Jurnal Penelitian Biologi, 5(1), 39-47.

[8] Imran, A. (2019). Hubungan Kekerabatan Kupu-Kupu (Ordo Lepidoptera) Berdasarkan Ciri Morfologi Di Taman Wisata Alam Kerandangan. JISIP (Jurnal Ilmu Sosial dan Pendidikan), 3(3).

[9] Gosal, L. M., Memah, V., \& Rimbing, J. (2016). Keanekaragaman dan Perbedaan Jenis Kupu-kupu (Ordo Lepidoptera) Berdasarkan Topografi pada Tiga Lokasi Hutan di Sulawesi Utara Diversity and Differences type of Butterfly species (Order Lepidoptera) based on the topography of the three forest location in. JURNAL BIOS LOGOS, 6(2).

[10] Meylani, V., \& Chaidir, D. M. (2019). Pengembangan Kawasan Konservasi Berbasis Etnozoologi bagi Masyarakat Sekitar Kawasan Cagar Alam "Leuweung Sancang”. BAKTIMAS: Jurnal Pengabdian pada Masyarakat, 1(2), 95-100.

[11] Bariyah, K. (2011). Hubungan panjang probosis kupu-kupu dengan preferensi pakan 
di areal kampus i Universitas islam negeri (UIN) syarif Hidayatullah Jakarta.

[12] Koneri, R. (2016). Kelimpahan kupu-kupu (lepidoptera) di kawasan Cagar Alam Gunung Ambang Sulawesi Utara. Pro-Life, 3(2), 7182.
[13] Suswanto, B., Handoko, W., \& Sabiq, A. (2013). Model community development sebagai strategi pemberdayaan berbasis kearifan lokal. Jurnal Review Politik, 3(2), 298-312. 